\title{
Similative and Equative Constructions in Japhug
}

\author{
Guillaume Jacques \\ CRLAO-CNRS-INALCO
}

This paper documents equative, similative, comparative and superlative constructions on the basis of a corpus of narratives. It reveals a previously unsuspected wealth of constructions: no less than three main types of superlatives, and four types of equatives are attested, some including additional subtypes.

\section{Introduction}

This paper ${ }^{1}$ deals with equative and similative constructions in Japhug. It comprises five sections. First, I present general information on the Japhug language and its morphosyntax. Second, I provide an account of degree, comparative and superlative constructions, which have similarities, and even overlap with, equative constructions. Third, I discuss similative constructions and how they relate to the equative constructions presented in section 4. Fourth, I describe the four types of equative constructions in Japhug. Fifth, I show some data on property equative constructions, which are not normally used in Japhug but have been collected using a novel method of elicitation.

\section{Background}

Japhug is a Gyalrong language (Trans-Himalayan, Gyalrongic; see Sun 2000 and Jacques \& Michaud 2011 for more information on the classification of this language) spoken in Mbarkham county, Rngaba prefecture, Sichuan province (China), by less than 10000 speakers. $^{2}$

Japhug and other Gyalrongic languages are polysynthetic, with a very rich and irregular morphology, and are highly head-marking (Jacques 2013b, Sun 2014), unlike some better known Trans-Himalayan languages such as Chinese or Burmese.

In this section, I discuss four topics of Japhug morphosyntax that are relevant to the description of the constructions studied in the paper: the definition of the word class 'adjective' in Japhug, general information on grammatical relations, orientation prefixes and possessive prefixes.

\subsection{Adjectives}

In Japhug, adjectives are a sub-class of stative verbs. They are conjugated and take TAM and person indexes for one argument. They can be distinguished from other stative verbs, like copulas, existential verbs and some modal auxiliaries by the fact that the tropative derivation can be applied to them (Jacques 2013a).

1I would like to thank Graham Thurgood, Yvonne Treis, Brigitte Pakendorf and one anonymous reviewer for useful comments on this paper. Glosses follow the Leipzig glossing rules. Other abbreviations used here include: AUTO spontaneous-autobenefactive, CISLOC cislocative, FACT factual/assumptive, GENR generic, IFR inferential evidential, INV inverse, LINK linker, SENS sensory evidential, SFR sentence final particle, TRANSLOC translocative, TROP tropative. Chinese borrowings in Japhug are indicated in pinyin between chevrons. The examples are taken from a corpus that is progressively being made available on the Pangloss archive (Michailovsky et al. 2014, http://lacito.vjf.cnrs.fr/ pangloss/corpus/list_rsc.php?lg=Japhug). This research was funded by the HimalCo project (ANR-12-CORP-0006) and is related to the research strand LR-4.11 "Automatic Paradigm Generation and Language Description" of the Labex EFL (funded by the ANR/CGI).

2Previous work on this language includes a grammar (Jacques 2008), a dictionary (Jacques 2015), and a series of articles on specific grammatical topics (see for instance Jacques 2013b, 2014, 2016c). 
In Japhug, it is possible to build a transitive verb meaning 'to find $X$, to consider as $X$ ' out of any adjective by means of the $n \gamma$ - prefix, as $m p 6 r r$ 'be beautiful' $n \gamma-m p 6 r r$ 'find $\mathrm{X}$ beautiful' or сqras 'be intelligent' $n \gamma-6 q r a s$ 'find X intelligent'.

\begin{tabular}{|c|c|c|c|c|c|}
\hline kuki & 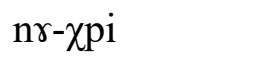 & pu-f6at-a & $\mathrm{ki}$ & wuma & zo \\
\hline DEM:PROX & 2SG.POSS-story & PFV-tell-1SG & DEM:PROX & really & EMPH \\
\hline \multicolumn{2}{|c|}{ u-nu-tut-nr-mperr } & nr & & & \\
\hline \multicolumn{2}{|c|}{ QU-SENS-2-TROP-be.beautiful } & if & & & \\
\hline
\end{tabular}

This derivation cannot be applied to copulas or existential verbs. ${ }^{3}$

\subsection{Flagging and person indexation}

A conjugated verb form without overt arguments is the minimal complete sentence in Japhug, and grammatical relations are mainly expressed by person indexation, which includes up to two arguments following a direct/inverse system (on which see Sun \& Shidanluo 2002, Jacques 2010, Gong 2014).

Overt noun phrases take case markers such as the ergative/instrument $k u$, the genitive $y u$ and the dative $u$-cki. There are no prepositions. Comitative adverbs are built by means of a prefix and are in the process of being grammaticalized as a quasi-case marker (Jacques 2017).

\subsection{Orientation prefixes}

All finite verb forms, except the factual non-past, require an orientation prefix (Table 1). Motion verbs and concrete action verbs are compatible with all prefixes, but most verbs can only take one or two orientation prefixes. For those verbs, the possible orientations are lexically specified; for instance $n d z a$ 'eat' and $t s^{h} i$ 'drink' take the 'up' and 'towards east' orientations respectively; 'eat' can also appear with the 'downstream' orientation in the case of meat-eating animals.

\begin{tabular}{|c|c|c|c|c|}
\hline & Perfective (A) & Imperfective (B) & Perfective $3 \rightarrow 3^{\prime}(\mathrm{C})$ & Evidential (D) \\
\hline up & tr- & tu- & ta- & to- \\
\hline down & puI- & pjü- & pa- & pjr- \\
\hline upstream & $1 \gamma-$ & lu- & la- & lo- \\
\hline downstream & $\mathrm{t}^{\mathrm{h}} \mathrm{UI}-$ & $\mathrm{c}^{\mathrm{h}} \mathrm{UI}-$ & $\mathrm{t}^{\mathrm{h}} \mathrm{a}-$ & $\mathrm{c}^{\mathrm{h}} \gamma-$ \\
\hline east & $\mathrm{kr}-$ & ku- & ka- & ko- \\
\hline west & nul- & nu- & na- & nr- \\
\hline no direction & jr- & ju- & ja- & jo- \\
\hline
\end{tabular}

Table 1. Orientation prefixes in Japhug Rgyalrong

${ }^{3}$ The verb тав 'not be' has a tropative form nry-тав 'consider to be unjustified', which however derives from its secondary meaning 'be incorrect'. 
Some particular constructions however can override the lexically selected orientation and impose a specific one; this is the case of one of the superlative constructions described in this paper (section 2.3.3).

\subsection{Possessive prefixes}

Nouns and nominalized verb forms can take a series of possessive prefixes related to the pronouns, as indicated in Table 2.

\begin{tabular}{lll}
\hline Free pronoun & Prefix & Person \\
\hline azo, aj & a- & $1 \mathrm{SG}$ \\
nrzo, nrj & nr- & $2 \mathrm{SG}$ \\
uzo & u- & $3 \mathrm{SG}$ \\
\hline t6izo & tci- & $1 \mathrm{DU}$ \\
ndzizo & ndzi- & 2DU \\
zrni & ndzi- & 3DU \\
\hline izo, izora, izrra & i- & 1PL \\
nuzo, nuzora, nuzrra & nu- & 2PL \\
zara & nu- & 3PL \\
\hline & tur-, tr- & indefinite \\
tuzo & tul- & generic
\end{tabular}

Table 2. Pronouns and possessive suffixes

The degree nominals, which are used in many of the constructions described in this paper (sections 2.1.2, 4.2 and 5) are derived from adjectives by prefixing the nominalizing prefix tu- (also used to make action nominals) together with a possessive prefix coreferent with the subject.

\section{Related constructions}

Before presenting equative constructions, I provide a brief account of three types of related constructions: degree, comparative and superlative, some of which present commonalities with the constructions described in section 4.

\subsection{Degree construction}

The degree of an adjectival predicate can be expressed in two ways, either with a degree adverb, or using the nominalized degree construction. 


\subsubsection{Degree adverb}

The degree adverb construction is very common cross-linguistically; it involves the adverb wuma 'really, very' (often with the emphatic marker $z 0$ ), which can appear either close to the adjective (as in 2) or separated from the verb by a noun phrase as in (3).

$\begin{array}{llllll}\text { (2) tce nunu } & \text { wuma } & \text { zo } & \text { t6ur } & \text { ri } \\ \text { LNK DEM } & \text { really } & \text { EMPH } & \text { be.sour:FACT } & \text { but } \\ \text { 'It is very sour.' }(09 \mathrm{mi}, 67) & & \end{array}$

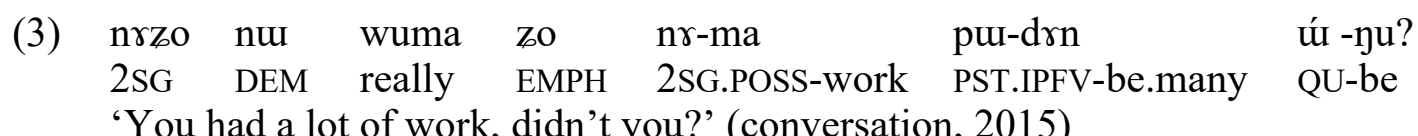

Although wuma 'really, very' is borrowed from Tibetan yo.ma 'true, real', this word is not used in this way in Tibetan languages as far as I know, and despite the deep typological and lexical influence of Tibetan on Japhug, the expression of degree in Tibetan uses unrelated constructions (Simon \& Hill 2015).

\subsubsection{Nominalized degree construction}

Another construction expressing degree in Japhug involves nominalizing the adjectives by means of the nominalization prefix $t u$ - and adding a possessive prefix coreferent with the subject (see section 1.4), as in the form $u$-tu-t6ur 'its (degree of) sourness' in example (4), followed by a predicate expressing the degree such as saxas 'be extremely' in this example. Other possible predicates include $t_{6}{ }^{h} \mathrm{Om}$ 'be too much' or naxteury 'be identical'; in the latter case it becomes an equative construction (see section 4.2). As shown in (5), the degree nominal ( $u$-tu-t6ur' its (degree of) sourness') can be followed by the marker ${ }^{4} \mathrm{~km}$ and a full clause describing the degree of the property described by the adjective ('so $\mathrm{X}$ that $\mathrm{Y}$ ').
(4)
$\begin{array}{lll}\text { mt }^{\text {hi }} & \text { u-mat } & \text { rca } \\ \text { sea.buckthorn } & \text { 3SG.POSS-fruit } & \text { UNEXPECTED }\end{array}$
u-tu-teur
saхав
3SG-NMLZ:DEGREE-be.sour be.extremely:FACT
'The fruit of the sea-buckthorn is very sour,' ('The degree of sourness of the fruit of the sea-buckthorn is extreme', $09 \mathrm{mi}, 65$ )

\footnotetext{
${ }^{4}$ This marker is formally identical, and historically related to, the ergative $k w$; see Jacques (2016b) for a more detailed discussion.
} 


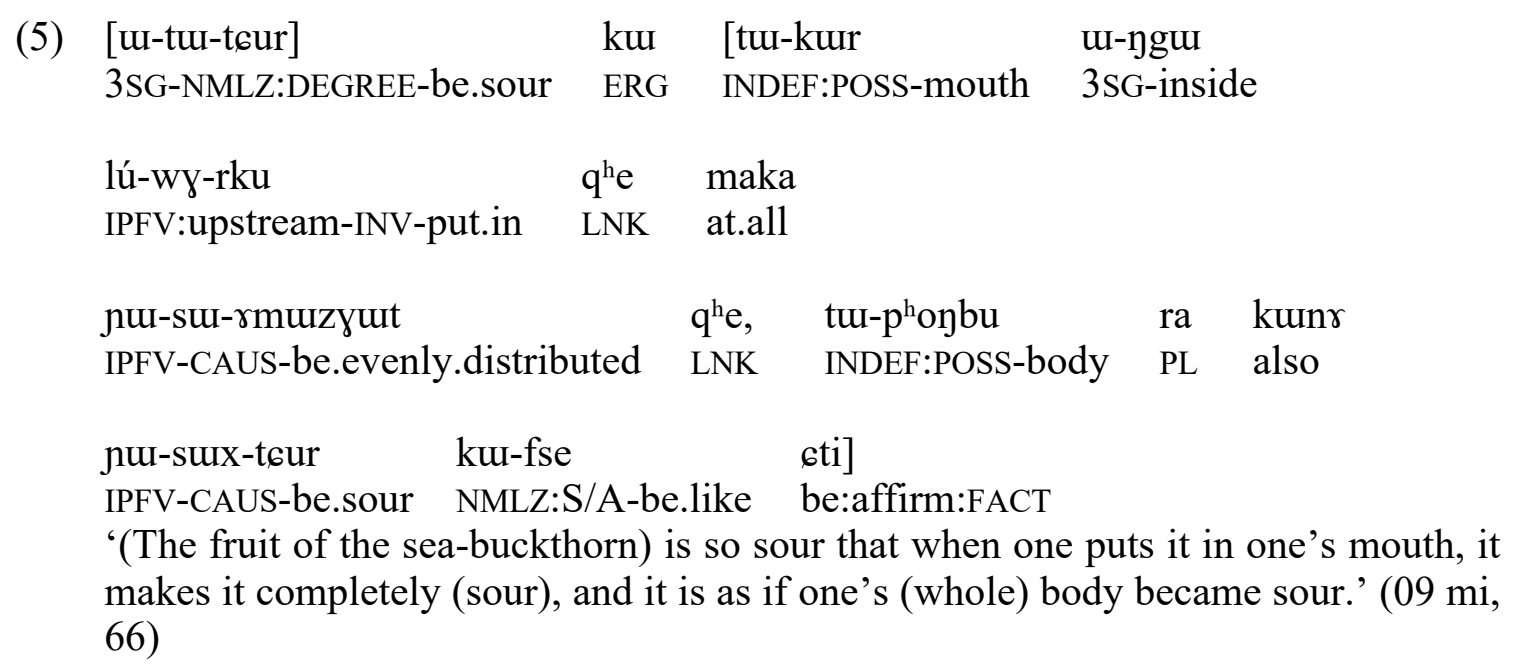

This construction is common in Japhug (Jacques 2016b: 8) and attested in other Rgyalrong languages such as Tshobdun (Sun 2006: 911).

\subsection{Comparative}

The comparative construction in Japhug can be illustrated by example (6): the standard is marked by the postposition $s \gamma z$ 'than' specifically used in this construction, and the comparee is marked by the ergative $k m$. In comparative constructions, it is common for ergative or instrumental markers to be used with the standard, but this use on the comparee is unexpected (Jacques 2016b).

(6)

\begin{tabular}{|c|c|c|c|}
\hline \multirow{2}{*}{\multicolumn{2}{|c|}{$\begin{array}{l}\text { ш-ві } \\
\text { 3SG.POSS-younger.sibling }\end{array}$}} & srz & \multirow{2}{*}{$\begin{array}{l}\text { [u-pi } \\
\text { 3sG.POSS-elder.sibling }\end{array}$} \\
\hline & & COMPARATIVE & \\
\hline nu] & mperr & & \\
\hline DEM & ERG be.beautiful & $\mathrm{ACT}$ & \\
\hline
\end{tabular}

\subsection{Superlative}

There are no less than three constructions expressing superlative meaning in Japhug: a degree adverb meaning 'most', a possessed subject participle (' $\mathrm{Y}$ is the $\mathrm{X}$ one of ...') and a relative clause with a negative existential verb ('There is no $\mathrm{X}$ one like $\mathrm{Y}$ ').

\subsubsection{Degree adverb}

The degree adverb superlative with stu most' is a familiar construction, illustrated by example (7) with an adjective in finite form (factual non-past).

$\begin{array}{llllll}\text { (7) nu } & \text { pyrtcu } & \text { nu-nguz } & \text { stu } & \text { xtci } & \text { lo } \\ \text { DEM } & \text { bird } & \text { 3PL.POSS-among } & \text { most } & \text { be.small:FACT } & \text { SFP }\end{array}$

'It is the smallest of all birds.' (hist-24-ZmbrWpGa, 126) 
The form - $y g u z$ is the irregular fusion of the relator noun - $\eta g m$ 'inside' and the locative $z u$ (it is thus a particular case of locative superlative construction, also found in many languages, e.g. Kambaata in this volume, Treis to appear).

Most examples of this construction appear however with adjectives in subject participle form, ${ }^{5}$ prefixed with $k u$ - as $k u-\eta r n$ 'the evil/terrible one' in (8).

$\begin{array}{llllll}\text { (8) kucungu } & \text { t6e } & \text { <aizheng> } & \text { kr-ti } & \text { pu-me } & \text { t6e, } \\ \text { long.ago } & \text { LNK } & \text { cancer } & \text { NMLZ:P-say } & \text { PST.IPFV-not.exist } & \text { LNK }\end{array}$

$\begin{array}{lllll}\text { kr-ku-nrndza } & \text { nu } & \text { stu } & \text { zo } & \text { ku-yrn } \\ \text { PFV-NMLZ:S/A-have.leprosy } & \text { DEM } & \text { most } & \text { EMPH } & \text { NMLZ:S/A-be.evil }\end{array}$

kr-pa pur-nu

NMLZ:P-consider PST.IPFV-be

'In former times, nobody talked about cancer, and leprosy was considered to be the most terrible (of all diseases).' (hist-25-khArWm, 35)

It is also possible to find this construction with oblique participles, as in (9), the only such example in the corpus.

$$
\begin{array}{lllll}
\text { stu } & \text { u-sr-drn } & \text { nu } & \text { strmku } & \text { nura } \\
\text { most } & \text { 3SG.POSS-NMLZ:OBLIQUE-be.many } & \text { DEM } & \text { prairie } & \text { DEM:PL }
\end{array}
$$

yu-nu

be:FACT-PL

'The places where most of them are are the prairies.' (hist-19-qachGamWntoR, 24)

\subsubsection{Possessed participle}

Another possibility to express superlative meaning is with an adjective in participial form with a third plural possessive marker, as in (10).

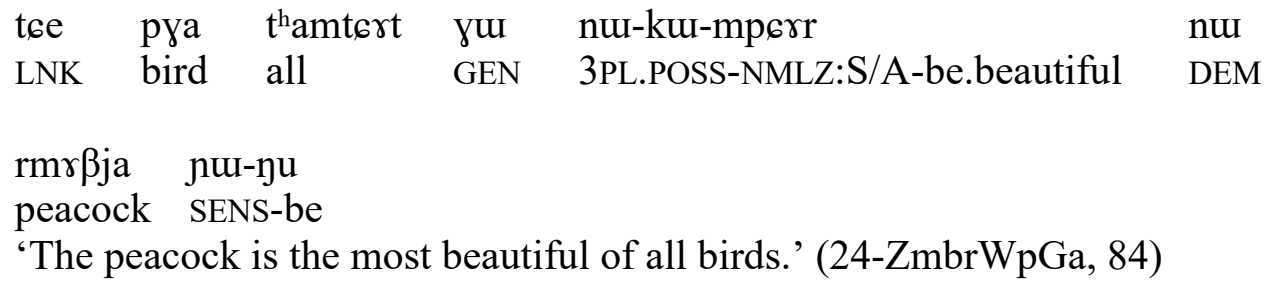

This construction is less common, and mainly occurs with the adjectives $m p 6 r r$ 'be beautiful' and mna 'be well'.

\subsubsection{Relative clause}

A more idiomatic way of expressing superlative meaning in Japhug is by means of a negative existential verb combined with a relative clause (indicated between square brackets in the

\footnotetext{
${ }^{5}$ For an account of participial forms and a definition of subjects and objects in Japhug, see Jacques (2016c,a). See also Sun $(2003,2014)$ with a slightly different terminology on Tshobdun and other Rgyalrong languages.
} 
following examples) and an adjunct with the participial form of $f_{s e}$ 'be in this way, be like (this)', as in (11). This construction is a particular use of the equative construction described in section 4.1. ${ }^{6}$

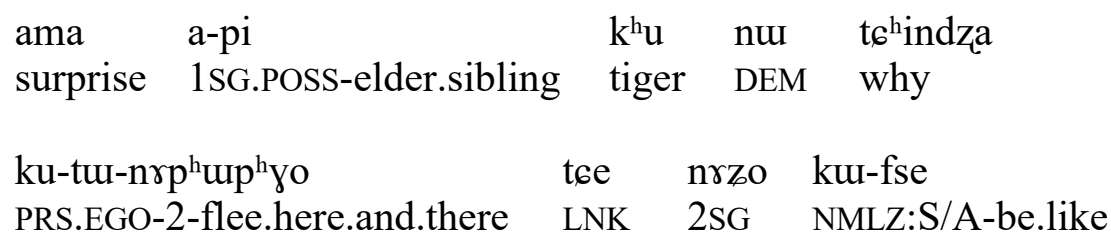

[ku-srymu] me NMLZ:S/A-be.dreadful not.exist:FACT

'Brother tiger, why are you running away like that, you are the most dreadful (animal).' (literally 'There is no one dreadful like you') (2005khu, 25)

This construction is potentially ambiguous ( $k u-s \gamma \gamma m u$ me can be interpreted as meaning both 'it is the most dreadful' or 'there is nothing dreadful'), and when the relative clause contains a finite main verb (when the relativized element is the object, the semi-object or the goal see Jacques $2016 \mathrm{c}$ ), it is possible in some cases to use orientation prefixes to disambiguate. In example (12), the verbs tso 'understand' and suz 'know' in the superlative construction take the 'up' prefix $t u$ instead of the expected 'towards east' ( $k u$-tso IPFV:east-understand 'he understands') and 'down' (pju-swz IPFV:down- know 'he knows') prefixes that they respectively select to build most tenses (see section 1.3).

With the 'up' prefix $t u$ - as in (12), only the superlative interpretation is possible, while with the 'down' prefix pju- as in (13) the superlative interpretation is excluded, and only the negative existential one is found.

I interpret this difference as a matter of semantic scope. In (12), the adjunct nu ku-fse 'like that' is outside of the scope of the negation, and the negation applies to the minimal relative clauses ${ }^{7} t u$ - $t s o-a$ '(that) I understand' and tu-suz- $a$ '(that) I know' ('[there is nothing that I understand/know] like that') exclusively.

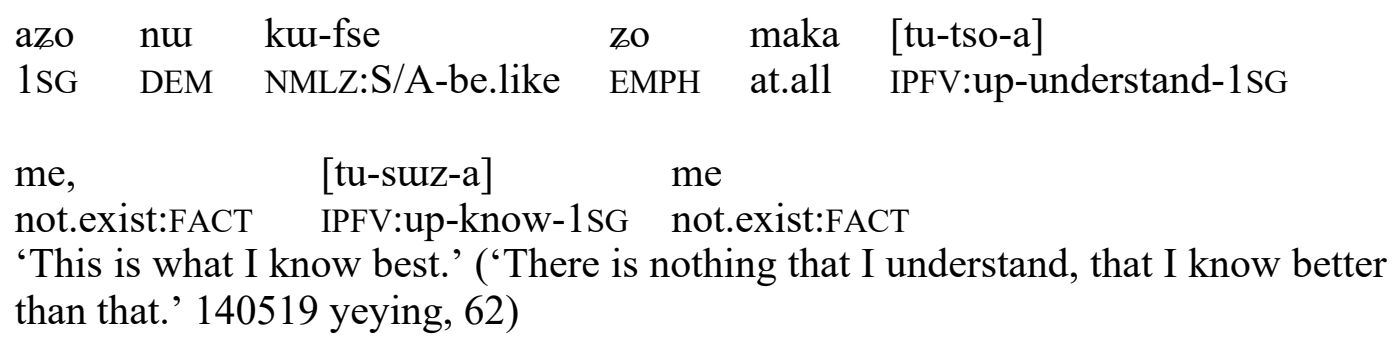

With the 'down' prefix pju- on suz 'know' as in (13), the scope of the negation is different: it applies to the whole constituent indicated between square brackets ('there is nothing like that that I know').

\footnotetext{
${ }^{6}$ No construction exactly identical to the Japhug one is found in Gorshenin's (2012) survey of superlatives, though it is close to the type described in his section 3.2.5.

${ }^{7}$ In Japhug finite clauses without any relativizer can be used to built object relative clauses, see Jacques (2016c).
} 

(13)

\begin{tabular}{|c|c|c|c|c|}
\hline [azo & nu & ku-fse & pju-suz-a] & me \\
\hline $1 \mathrm{SG}$ & DEM & NMLZ:S/A-be.like & IPFV:down-know-1SG & not.exist:FACT \\
\hline
\end{tabular}

This contrast cannot however be generalized to all verbs; more research is necessary to ascertain the extent, and the functional explanation for this puzzling phenomenon.

\section{Similative}

In Japhug, the main similative construction involves the verbs $f_{s e}$ 'be like (this)' (intransitive stative) and stu 'do (this) way, do like (this)' (transitive). These verbs can occur in a serial verb construction, having the same core arguments and TAM values as the main verb, as illustrated by (14) (TAM: imperfective; Person: $3 \mathrm{pl} \rightarrow 1 \mathrm{sg}$ ) and (15) (TAM: factual non-past; Person:1sg). It is possible to insert a linker between the two verbs of the serial construction, as in example (14).

$\begin{array}{lllll}\text { azo } & \text { kuki } & \text { ntsu } & \text { kú-wy-stu-a-nu } & \text { t6e, } \\ \text { 1SG } & \text { DEM:PROX } & \text { always } & \text { IPFV-INV-do.like-1SG-PL } & \text { LNK }\end{array}$

kú-wy-znuk ${ }^{\mathrm{h}}$ rum-a-nu IPFV-INV-punish-1SG-PL

'They punished me like this.' (Gesar, 278)

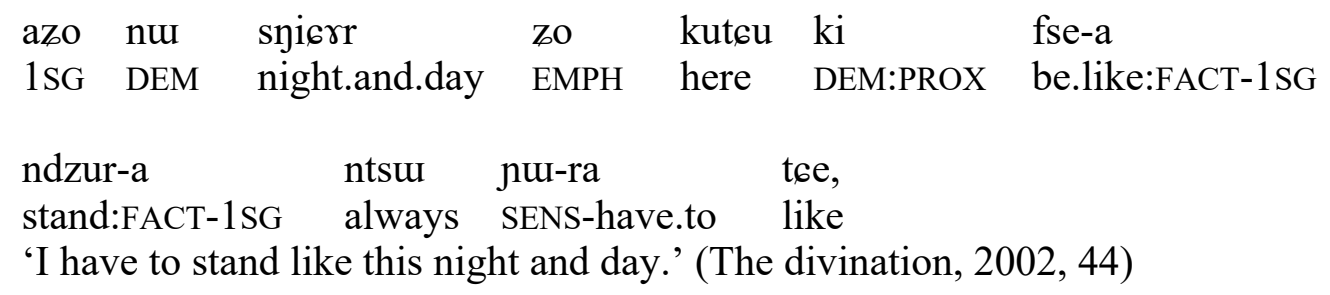

The standard (the demonstrative pronouns kuki in (14), and ki in (15)) cannot be indexed on the verb. The verb stu 'do (this) way, do like (this)' is thus secundative ditransitive, taking the standard as its theme.

The equative construction in $f s e$ 'be like (this)' (section 4.1) is a particular case of this serial verb construction, when the main verb is an adjective.

With dynamic verbs, the standard is almost always a demonstrative as in (14) and (15) above. Exceptions include 16, where the standard is the noun turme 'man'. In this example, the verb $f s e$ 'be like (this)' takes the sensory form (with the $n u$ - prefix), while the main verb is in a periphrastic sensory form, combining the verb in the imperfective (tu-ndze 'it eats') with an auxiliary in the sensory form.

$$
\begin{array}{llllllll}
\text { pri } & \text { nu } & \text { ku, } & \text { turme } & \text { ju-fse } & \text { t6e, } & \text { tr-rrku } & \text { t6i } \\
\text { bear } & \text { DEM } & \text { ERG } & \text { man } & \text { SENS-be.like } & \text { LNK } & \text { INDEF.POSS-grain } & \text { also }
\end{array}
$$

tu-ndze, 6a t6i tu-ndze, $\quad \ldots \quad$ nu-ngrrl IPFV-eat meat also IPFV-eat SENS-be.usually.the.case

'The bear, like a man, eats grains and meat.' (21-pri, 17) 


\section{Entity equative}

This section discusses the entity equative constructions, i.e. constructions expressing that two entities have a property in equal degree (' $\mathrm{X}$ is as $\mathrm{Y}$ as $\mathrm{Z}$ '). It differs from the parameter equative, treated in section 5, expressing that the same entity has two properties in equal degree (' $\mathrm{X}$ is a $\mathrm{Y}$ as he is Z'). In the following, I adopt the terminology proposed by Haspelmath \& Buchholz (1998), as illustrated by the English example (17).

$\begin{array}{lll}\text { (17) John } & \text { is as } & \text { intelligent } \\ \text { COMPAREE } & \text { PARAMETER.MARKER } & \text { PARAMETER }\end{array}$
$\begin{array}{ll}\text { as } & \text { Paul } \\ \text { STANDARD.MARKER } & \text { STANDARD }\end{array}$

There are no less than four distinct constructions expressing argument equative meanings in Japhug.

\section{1.fse 'be like'}

One equative construction is built with the verb $f_{s e}$ 'be like (this)' (or more rarely naxt6my 'be identical' and afsuja 'be of the same size'). The verb $f s e$ 'be like (this)' is stative, but takes two arguments (respectively the comparee and the standard). Since it is syntactically linked to the standard, it is analyzed here as the standard marker rather than as the parameter marker.

Both the standard marker fse 'be like (this)' and the parameter can appear in finite form, sharing TAM and person marking as in (18). This is in fact a particular case of the serial verb construction used to express similative (see section 3). Such examples with finite verb forms are rare in the corpus.

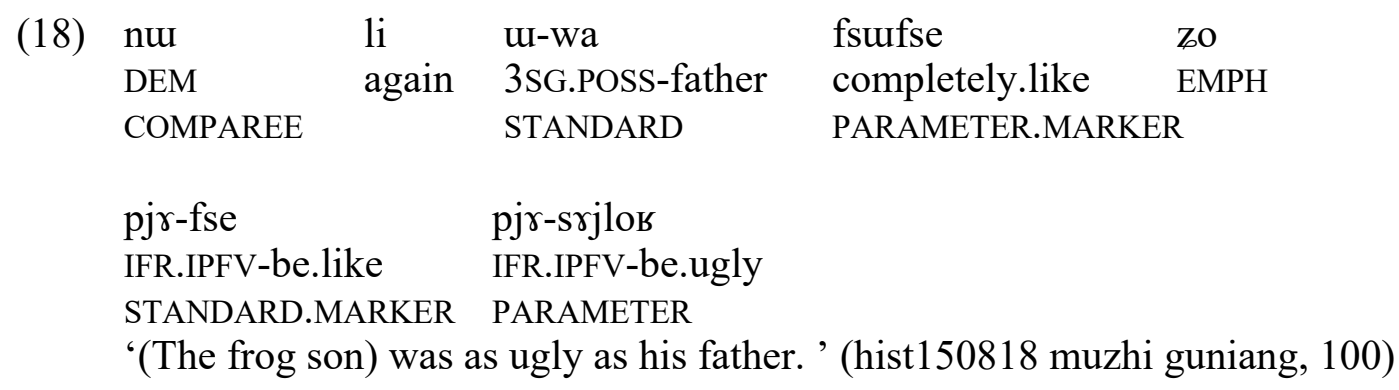

The verb naxt6my 'be identical' used a similar construction requires in addition the comitative $c^{h} O$ on the standard, as shown by example (19). 
(19)

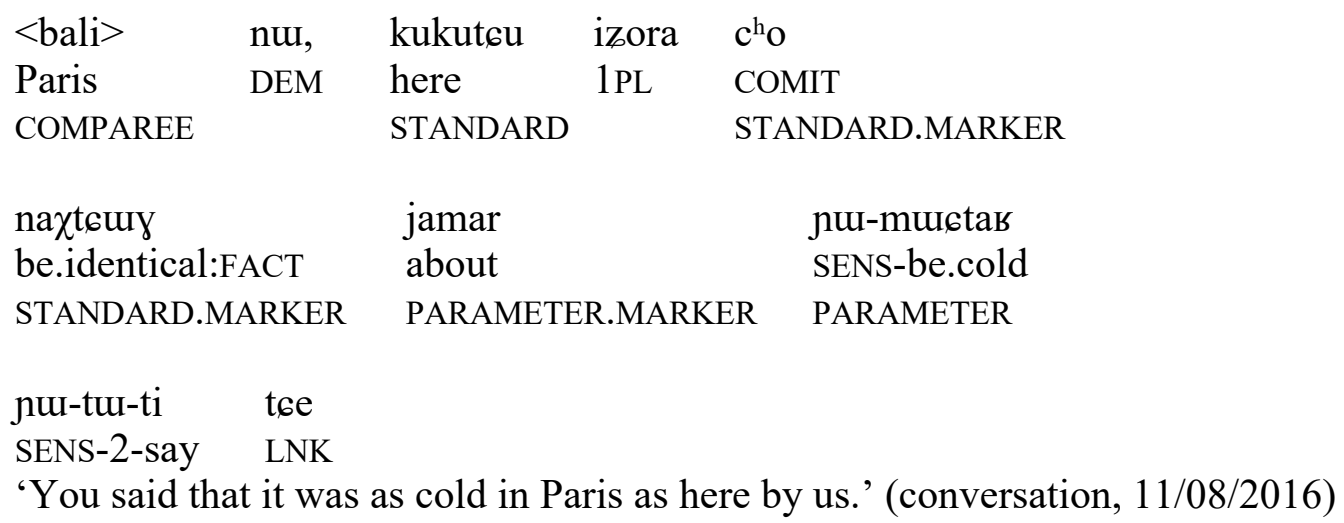

The equative construction in $f s e$ 'be like (this)' is more commonly used in attributive equative clauses. Both $f_{s e}$ 'be like (this)' and the adjective (the parameter) are in participial form in (20), forming a relative clause with the comparee as the relativized element. The superlative construction studied in section 2.3.3 is essentially a particular use of such relativized equative sentences.

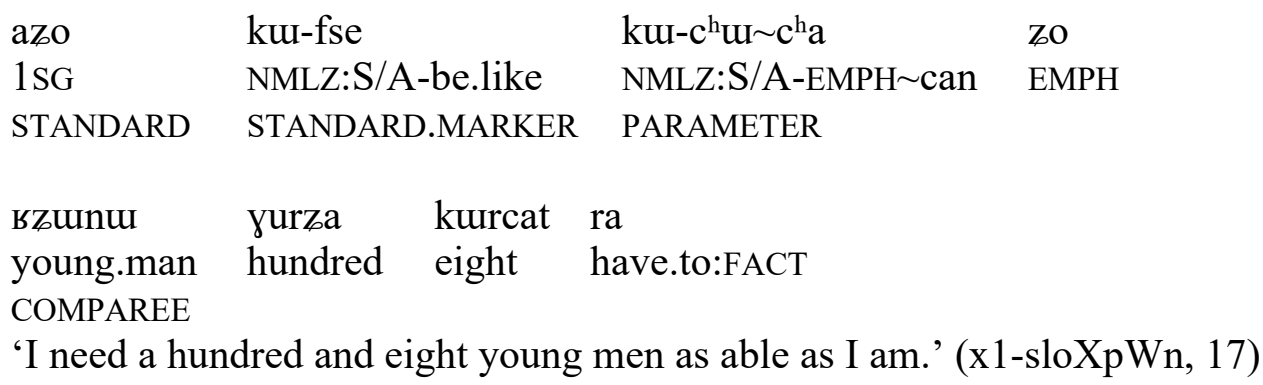

These constructions do not require a parameter marker, though adverbs $f$ sufse 'completely identical' can serve as an emphatic parameter marker, as in (18).

A similar equative construction is attested in the Kyomkyo dialect of Situ Rgyalrong (Prins 2011: 238), though with the standard marker expressed by the participial form of the Tibetan loanword $n d z a$ 'be like' instead of the native root corresponding to Japhug fse 'be like (this)'. This equative construction corresponds to Haspelmath et al.'s (2017) type 1 (Only equative standardmarker).

\subsection{Nominalized degree construction}

This construction is a particular case of the Nominalized Degree Construction presented in section 2.1.2. It is by far the most common way of expressing equative meaning in Japhug. It has three slightly different variants.

In the first construction (corresponding to Haspelmath et al.'s (2017) type 5 - Primary reach equative unified), the comparee and the standard are included in a noun phrase, with the comitative marker $c^{h} O$ (and its longer variant $c^{h} O n d r r e$ ) serving as the standard marker between them. ${ }^{8}$ This

\footnotetext{
${ }^{8}$ In this construction, since the comparee and the standard are included in the same constituent, only the context allows to distinguish between the two. In this example, we know that the $\beta$ zar bird is the standard since this sentence is taken from a text describing the qalekuts $i$ bird. This illustrates the fact that in equative constructions, since standard and comparee are identical with respect to a particular parameter, exchanging their order has no impact on the truth value
} 
noun phrase is followed by an adjective (the parameter) in degree nominal form (prefixed with $t w-)$ and a possessive prefix (in dual or plural) coreferent with the preceding noun phrase. This nominalized verb and the preceding noun phrase form a larger noun phrase that is the subject of the adjective naxt6ur 'be identical' (the parameter marker) ${ }^{9}$ in finite form, as in (21) and (22).

$\begin{array}{lllll}\text { qalekuts }^{\mathrm{h}} \mathrm{i} & \text { numu } & \mathrm{c}^{\mathrm{h}} \text { ondrre } & \beta \text { zar } & \text { nu } \\ \text { bird.sp } & \text { DEM } & \text { COMIT } & \text { bird.sp } & \text { DEM } \\ \text { COMPAREE } & & \text { STANDARD.MARKER } & \text { STANDARD }\end{array}$

ndzi-tur-wxti

naxt6ur

3DU.POSS-NMLZ:DEGREE-be.big

be.identical:FACT

PARAMETER

PARAMETER.MARKER

'The qalekwts ${ }^{h}$ bird is as big as the $\beta$ zar bird.' ('The qalekuts ${ }^{h} i$ bird and the $\beta z a r$ bird are identical in their degree of bigness') (hist-23- RmWrcWftsa, 34)
mr-mbro
trru $\quad \mathrm{c}^{\mathrm{h}} \mathrm{O}$
ndzi-tu-mbro
NEG-be.high:FACT tree.sp COMIT 3DU.POSS-NMLZ:DEGREE-be.high
naxt6uly
be.identical:FACT
'It is not high, it (grows) as high as the trru tree.' (hist-17-xCAj, 56)

In the second construction, ${ }^{10}$ the nominalized parameter takes a possessive prefix only coreferent with the comparee, and the standard together with the comitative (the standard marker) follows the parameter, as in (23).

$\begin{array}{lllll}\text { qalias } & \text { nu } & \text { u-tu-wxti } & \text { nu } & \text { qandzyi } \\ \text { eagle } & \text { DEM } & \text { 3SG.POSS-NMLZ:DEGREE-be.big } & \text { DEM } & \text { hawk } \\ \text { COMPAREE } & \text { PARAMETER } & & \text { STANDARD }\end{array}$

$\begin{array}{lll}\mathrm{c}^{\mathrm{h}} \mathrm{O} & \text { naxt6uy } & \text { tsa } \\ \text { COMIT } & \text { be.identical:FACT } & \text { a.little } \\ \text { STANDARD.MARKER } & \text { PARAMETER.MARKER } & \text { PARAMETER.MARKER } \\ \text { 'The eagle is about as big as the hawk.' (19-qandZGi, 36) }\end{array}$

In the third construction, the parameter takes a third person singular possessive prefix, and the two comparees are indicated by person indexation on the verb. In (24), the standard and the comparee are the speaker and the addressee; they are not expressed by overt pronouns, but are rather indexed on the verb by the suffix $-t 6 i$.

of the sentence, unlike in the case of other comparative constructions.

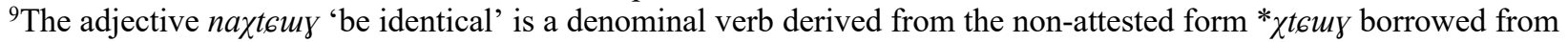
the Tibetan numeral gt6ig 'one'.

${ }^{10}$ This construction is very rare, only two examples are found in the corpus. 


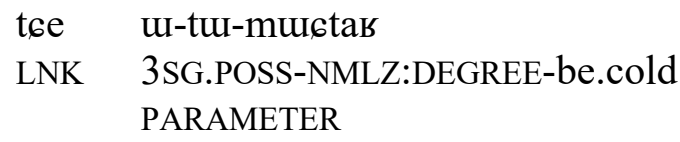

\subsubsection{Possessed noun}

The possessed noun ${ }^{11} u-f s u$ 'of the same size as' can be used as the standard marker in a construction of Haspelmath et al.'s (2017) type 1 like the one discussed in section 4.1.11. ${ }^{12}$ The parameter cannot be expressed in this construction.

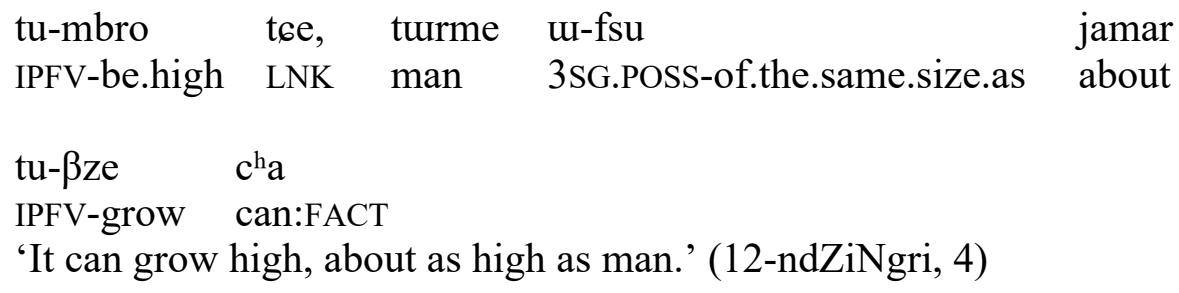

This construction is relatively marginal in Japhug. In the Cogtse dialect of Situ Rgyalrong, a similar construction is reported (Lín 1993: 377).

\subsection{Denominal adjectives}

Japhug has a denominal prefix arm-/rru- deriving adjectives meaning 'like $\mathrm{X}$ ' out of nouns. I have no examples from narratives, but it spontaneously occurs in conversation in examples such as (26) (which I heard as I was correcting the transcription of a story with my main informant), in a construction combining the degree nominal (2.1.2) with the sentence final particle $n u$ used to express surprise. Example (27) illustrates the same form with a non-denominal adjective.

$$
\text { u-tul-rrusujno nu! }
$$

3SG.POSS-NMLZ:DEGREE-be.like.grass SFP

'(She cuts their head as easily) as if it were grass.' (heard in context)

$\begin{array}{ll}\text { uU-tul-mpørr } & \text { nu! } \\ \text { 3SG.POSS-NMLZ:DEGREE-be.beautiful } & \text { SFP } \\ \text { 'It/s/he is so beautiful!' } & \end{array}$

\footnotetext{
${ }^{11}$ In Japhug, possessed nouns obligatorily take a possessive prefix (see Table 2, section 1.4), here the 3SG $u-$.

${ }^{12}$ Incidentally, note that $f s e$ 'be like (this)', the verb which serves as the standard marker in the construction described in section 4.1, is etymologically related to $m-f s u$ 'of the same size as'.
} 
The more elaborated sentence (28) was given as an explanation for (26).

$\begin{array}{lllll}\mathrm{kr}-\mathrm{p}^{\mathrm{h}} \mathrm{ut} & \mathrm{uI}-\mathrm{tu}-\mathrm{mbat} & \mathrm{ku} & \text { nut-rrusujno } & \text { zo } \\ \text { INF-cut } & \text { 3SG.POSS-NMLZ:DEGREE-easy } & \text { ERG } & \text { SENS-be.like.grass } & \text { EMPH } \\ \text { 'It is as easy to cut as if it were grass, } & & \end{array}$

This unusual equative construction is productive, since it can be applied to nouns from Tibetan or Chinese. It does not fit in any of Haspelmath et al.'s (2017) six types of equative constructions, but resembles the "similative adjective" derivation in -lágan in Saami (Ylikoski to appear: 5.1). There are three main differences between the Japhug construction and its Saami equivalent.

1. The denominal adjectives in Japhug are a sub-class of stative verbs, rather than being noun-like as in Saami.

2. The suffix -lágan in Saami, like the corresponding equative postposition láhkai are historically related to the noun láhki 'mood, manner', whereas the prefix armappears to be a combination of the passive $a$ - with the denominal ru-prefix.

3. The Saami suffix is mainly used in attributive equative constructions, while the Japhug prefix occurs mainly in the degree nominal form illustrated by (26).

\section{Property equative}

Property equative constructions (' $\mathrm{X}$ is as $\mathrm{Y}$ as he is $\mathrm{Z}$ ') do not occur in the Japhug corpus. This meaning can however be expressed in this language. In order to limit the effect of elicitation, the following procedure was undertaken. I first wrote a Japhug translation of Perrault's story Riquet $\grave{a}$ la Houppe which contains many examples of property equative sentences. The translation was then corrected with my main informant sentence by sentence. Then, she was asked to retell the story (in six episodes of 3 to 5 minutes) using her own words.

Property equatives, e.g. ' $\mathrm{X}$ is as stupid as s/he is beautiful' (a sentence occurring several times in the story), can be expressed in Japhug in three distinct ways. First, the possessed noun $u-f s u$ 'of the same size as' (used in the argument equative construction, section 4.3), follows a degree nominal derived from the first adjective; the second adjective takes a finite form.

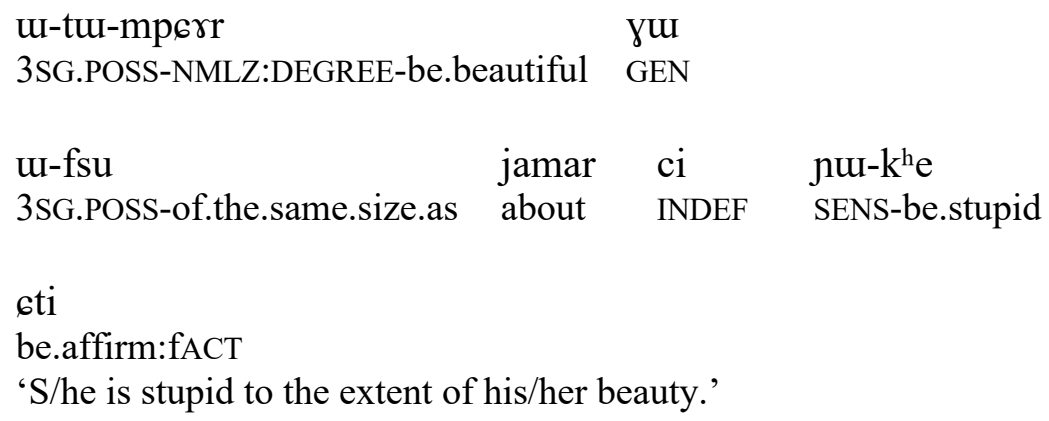

Second, two adjectives in degree nominal form, the first followed by the comitative postposition $c^{h} O$, are subject of the verb afsuja 'be of the same size'. This construction is the equivalent of the argument equative construction in section 4.2. 
(30)

$\begin{array}{ll}\text { u-tu-mperr } & \mathrm{c}^{\mathrm{h}} \mathrm{O} \\ \text { 3SG.POSS-NMLZ:DEGREE-be.beautiful } & \text { COMIT }\end{array}$

$\begin{array}{lll}\text { u-tw-k }{ }^{\text {he }} & \text { nut } & \text { nu-rfsuja } \\ \text { 3SG.POSS-NMLZ:DEGREE-be.stupid } & \text { DEM } & \text { SENS-be.of.the.same.size }\end{array}$

sti

be.affirm:FACT

'His/Her beauty and his/her stupidity are equal.'

Third, it is possible to express the same meaning with a correlative construction, as in (31). This construction however may be a calque from Chinese and is of lesser interest to the study of Japhug grammar.

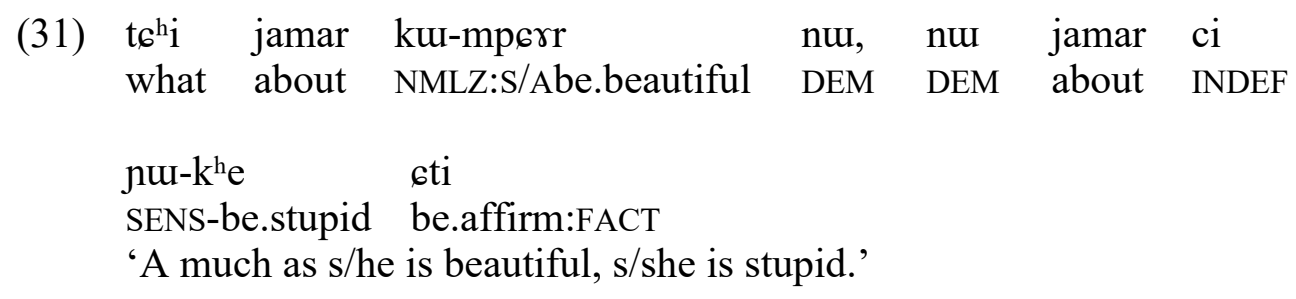

\section{Conclusion}

This paper documents various constructions in Japhug, some of which have never been described previously. Japhug presents a rich array of equative constructions, some of the garden variety type, but others, like the relative clause superlative (in particular the use of the 'up' orientation prefix, see section 2.3.3) and the denominal equative (section 4.4), appear quite unusual and isolated at least areally.

Despite the lexical influence of Tibetan languages on Japhug, and the fact that some of the constructions described in this paper involve Tibetan borrowings (see sections 2.1.1 and 4.2), none of them appear to be calqued from their Tibetan equivalents.

\section{References}

Gong, Xun. 2014. Personal agreement system of Zbu rGyalrong (Ngyaltsu variety). Transactions of the Philological Society 112(1). 44-60.

Gorshenin, Maksym. 2012. The crosslinguistics of the superlative. In Cornelia Stroh (ed.), Neues aus der Bremer Linguistikwerkstatt: Aktuelle Themen und Projekte 31, 55-160. Bochum: Bockmeyer.

Haspelmath, Martin \& Oda Buchholz. 1998. Equative and similative constructions in the languages of Europe. In Johan van der Auwera (ed.), Adverbial Constructions in the Languages of Europe, 277-334. Berlin, New York: Mouton de Gruyter.

Haspelmath, Martin and Leipzig Equative Constructions Team. 2017. Equative constructions in world-wide perspective. In Yvonne Treis \& Martine Vanhove (eds.), Similative and Equative Constructions: A Cross-Linguistic Perspective, pp. 9-32. Amsterdam: Benjamins.

Jacques, Guillaume. 2008. 嘉絨語研究 Jiāróngyǔ yánjiū (Study on the Rgyalrong language). Beijing: Minzu chubanshe. 
Jacques, Guillaume. 2010. The inverse in Japhug Rgyalrong. Language and Linguistics 11(1). 127-157.

Jacques, Guillaume. 2013a. Applicative and tropative derivations in Japhug Rgyalrong. Linguistics of the Tibeto-Burman Area 36(2). 1-13.

Jacques, Guillaume. 2013b. Harmonization and disharmonization of affix ordering and basic word order. Linguistic Typology 17(2). 187-217.

Jacques, Guillaume. 2014. Clause linking in Japhug Rgyalrong. Linguistics of the Tibeto-Burman Area 37(2). 263-327.

Jacques, Guillaume. 2015. Dictionnaire Japhug-Chinois-Français, version 1.0. Paris: Projet HimalCo. http://himalco.huma-num.fr/.

Jacques, Guillaume. 2016a. Complementation in Japhug. Linguistics of the Tibeto Burman Area 39(2). 222-281.

Jacques, Guillaume. 2016b. From ergative to comparee marker: multiple reanalyses and polyfunctionality. Diachronica 33(1). 1-30.

Jacques, Guillaume. 2016c. Subjects, objects and relativization in Japhug. Journal of Chinese Linguistics 44(1). 1-28.

Jacques, Guillaume. 2017. The origin of comitative adverbs in Japhug. In Walter Bisang \& Andrej Malchukov (eds.), Unity and Diversity in Grammaticalization Scenarios, 31-44. Berlin: Language Science Press.

Jacques, Guillaume \& Alexis Michaud. 2011. Approaching the historical phonology of three highly eroded Sino-Tibetan languages: Naxi, Na and Laze. Diachronica 28(4). 468-498.

Lín, Xiàngróng (林向榮). 1993. Jiāróngyǔ yánjiū 嘉戎語研究 [A study on the Rgyalrong language]. Chengdu: Sichuan minzu chubanshe.

Michailovsky, Boyd, Martine Mazaudon, Alexis Michaud, Séverine Guillaume, Alexandre François \& Evangelia Adamou. 2014. Documenting and researching endangered languages: the Pangloss Collection. Language Documentation and Conservation 8. 119-135.

Prins, Marielle. 2011. A Web of Relations: A Grammar of rGyalrong Jiaomuzu (Kyom-kyo) Dialects: Leiden University dissertation.

Simon, Camille \& Nathan W. Hill. 2015. Tibetan. In Nicola Grandi \& Livia Körtvélyessy (eds.), Edinburgh Handbook of Evaluative Morphology, 381-388. Edinburgh: Edinburgh University Press.

Sun, Jackson T.-S. 2000. Parallelisms in the Verb Morphology of Sidaba rGyalrong and Lavrung in rGyalrongic. Language and Linguistics 1(1). 161-190.

Sun, Jackson T.-S. 2003. Caodeng rGyalrong. In Graham Thurgood \& Randy LaPolla (eds.), The Sino-Tibetan Languages, 490-502. London: Routledge.

Sun, Jackson T.-S. 2006. 草登嘉戎語的關係句 Caodeng Jiarongyu de guanxiju (Relative clauses in the Tshobdun language). Language \& Linguistics 7(4). 905-933.

Sun, Jackson T.-S. 2014. Sino-Tibetan: Rgyalrong. In Rochelle Lieber \& Pavol Štekauer (eds.), The Oxford Handbook of Derivational Morphology, 630-650. Oxford: Oxford University Press.

Sun, Jackson T.-S. \& Shidanluo. 2002. Caodeng Jiarongyu yu rentong dengdi xiangguan de yufa xianxiang 草登嘉戎語與「認同等第」相關的語法現象 (Empathy Hierarchy in Caodeng rGyalrong grammar). Language and Linguistics 3(1). 79-99.

Treis, Yvonne. this volume. Comparison in Kambaata: Superiority, Equality and Similarity. Linguistic Discovery 16.1:65-101.

Ylikoski, Jussi. 2017. Similarity, equality and the like in North Saami. In Yvonne Treis \& Martine Vanhove (eds.), Similative and Equative Constructions: A Cross-linguistic Perspective, 259-290. Amsterdam: Benjamins. 